\title{
Pengaruh Kualitas Produk kartuHALO Terhadap Kepuasan Pengguna (Studi pada GraPARI Telkomsel MTC Bandung)
}

\author{
Oleh : \\ Dita Puspitasari dan Sri Surjani Tjahjawati \\ Politeknik Negeri Bandung
}

\begin{abstract}
:
Every company does business by producing a product or service with good quality. Quality is very important for the company because every company has its own standards based on specifications set. The quality is also very important for consumers because consumers who determine the needs and desires as well as closely related to satisfaction will be felt after using the product. Customer satisfaction is also very important for the company because the company trying to provide something that is needed, desired and sought after by consumers, and ultimately the consumer will be satisfied. Satisfaction is also very important for consumers because it is something to be gained by comparing the expectations of the performance of the products that have been purchased. This study aims to determine the effect on product quality kartuHALO user satisfaction in GraPARI MTC Telkomsel Bandung. The method used in this research is descriptive method, with the results stating that kartuHALO product quality and user satisfaction in GraPARI MTC Telkomsel Bandung is quite good. Of the eight dimensions of the variable product quality, performance dimension had the highest contribution is 4.14 and the dimensions of durability contribute to the bottom at 3.86. For user satisfaction, from the existing three-dimensional, dimensions of emotional factors contribute to the high at 4.02 and dimensions contribute to its lowest price of 3.66. This study used a questionnaire distributed to 270 respondents. Based on the research that has been done, regression equation $Y=7.483+0,283 X$. The study states that kartuHALO product quality and user satisfaction has a strong positive correlation of 0.582 and product quality kartuHALO affect user satisfaction of 33.9\%.
\end{abstract}

Keywords : Product quality, user satisfaction

\section{Latar Belakang Penelitian}

Dengan perkembangan dunia bisnis yang semakin hari semakin berkembang pesat, perusahaan dituntut untuk selalu dapat mengikuti perkembangan yang ada dengan berbagai cara yaitu menciptakan atau melakukan inovasi barang atau jasa, sehingga perusahaan dapat bersaing, berkembang, bertahan lama dan juga dapat memenuhi kebutuhan konsumen.

Salah satu cara agar perusahaan dapat bersaing, berkembang, bertahan lama dan juga dapat memenuhi kebutuhan konsumen adalah dengan cara memberikan perhatian lebih pada kebutuhan dasar konsumen sehari-hari, salah satunya adalah komunikasi. Komunikasi merupakan hal yang sangat penting dalam kehidupan sehari-hari yaitu untuk bersosialisasi dengan keluarga, saudara dan rekan. Komunikasi adalah suatu proses pengiriman dan penerimaan pesan atau informasi yang dilakukan oleh dua orang atau lebih agar informasi yang dimaksud dapat dipahami atau dimengerti oleh penerima.

Komunikasi yang dilakukan oleh manusia tidak selalu terjadi dengan bertatap muka secara langsung. Dengan perkembangan teknologi yang semakin pesat membawa manusia untuk dapat melakukan komunikasi dengan orang lain kapanpun dan dimanapun dengan 
cepat, sehingga jarak bukan lagi halangan untuk berkomunikasi. Teknologi komunikasi tersebut salah satunya adalah melalui telepon yaitu sebuah perangkat telekomunikasi elektronik yang dapat mengirimkan pesan berbentuk suara percakapan. Telepon atau perangkat telekomunikasi elektronik yang biasa digunakan adalah ponsel atau telepon genggam yang dapat dibawa kemana-mana karena tidak menggunakan kabel, sehingga memudahkan dalam mengirim pesan atau informasi dengan orang lain kapanpun dan dimanapun. Ponsel beroperasi dengan menggunakan transmisi sinyal elektrik dalam sebuah jaringan telepon, sehingga memungkinkan manusia sebagai pengguna telepon untuk dapat melakukan komunikasi berupa panggilan telepon atau mengirim pesan singkat kepada pengguna lainnya.

Dengan melihat kebutuhan dasar manusia yaitu komunikasi, dimana salah satunya dapat dilakukan dengan menggunakan perangkat ponsel atau telepon genggam yang membutuhkan transmisi sinyal elektrik dalam sebuah jaringan telepon, maka banyak perusahaan menjadikannya sebagai peluang bisnis yang menguntungkan dan dapat bertahan lama. Banyak perusahaan bersaing untuk dapat menyediakan jasa dan jaringan telekomunikasi dengan berbagai fitur menarik dan harga yang bersaing. Salah satu perusahaan yang bersaing adalah Telkomsel yang didirikan pada tahun 1995 yang menjadi operator atau penyedia jasa telekomunikasi dan jaringan telekomunikasi seluler. Telkomsel memiliki visi untuk mengembangkan telekomunikasi di Indonesia dan untuk mewujudkannya Telkomsel terus memacu pertumbuhan jaringan telekomunikasi di seluruh penjuru Indonesia secara pesat sekaligus memberdayakan masyarakat. Telkomsel menjadi pelopor untuk berbagai teknologi telekomunikasi selular di Indonesia dan memiliki banyak produk unggulan, salah satunya adalah kartuHALO.

kartuHALO adalah produk yang dirilis Telkomsel yang mengharuskan penggunanya untuk berlangganan agar dapat menikmati fitur-fitur menarik yang tersedia. kartuHALO merupakan kartu pascabayar (postpaid), dimana pada saat pengguna berlangganan, maka pengguna dapat menikmati fitur-fitur yang tersedia dan membayar pada bulan selanjutnya sehingga sangat memudahkan penggunanya karena tidak harus selalu mengisi pulsa.

Setiap perusahaan berusaha untuk menciptakan produk dengan kualitas yang baik, begitu pula dengan Telkomsel yang berusaha memberikan kualitas yang baik pada produkproduk yang dirilisnya. Dengan kualitas produk yang baik, maka akan berdampak pada kepuasan yang dirasakan oleh pengguna. Kepuasan pengguna adalah perasaan yang dirasakan oleh seseorang setelah menggunakan suatu produk atau jasa, perasaan tersebut didapat setelah membandingkan kinerja produk atau jasa dengan ekspektasi yang dimiliki.

GraPARI Telkomsel adalah pusat layanan Telkomsel yang memfokuskan diri untuk melayani pelanggan dan juga menyediakan penjualan produk Telkomsel. GraPARI Telkomsel MTC Bandung setiap harinya melayani pelanggan yang akan mendaftar menggunakan salah satu produk Telkomsel yaitu kartuHALO. Berikut ini adalah data jumlah pengguna baru kartuHALO selama tahun 2015, yaitu : 
Gambar 1 Grafik Jumlah Pengguna Baru kartuHALO Selama Tahun 2015

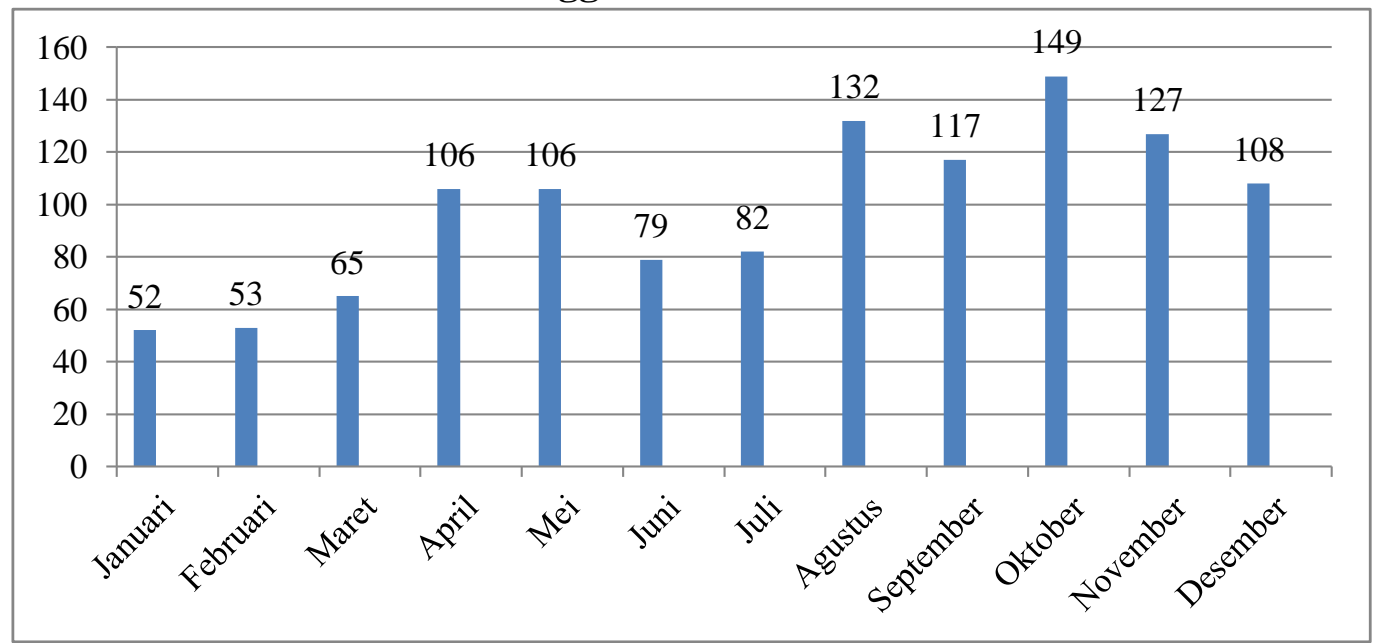

Sumber: Data Internal GraPARI Telkomsel MTC Bandung (2016)

Dapat dilihat dari Gambar 1.1 diatas, jumlah pelanggan yang mendaftar untuk menggunakan kartuHALO di GraPARI Telkomsel MTC Bandung fluktuatif setiap bulannya. Dari data diatas, dapat diakumulasikan jumlah pengguna kartuHALO selama Tahun 2015 sebanyak 1.176 pengguna. Dari banyaknya jumlah pengguna baru pada grafik diatas, membuktikan bahwa banyak orang yang mengharapkan kualitas yang baik dari kartuHALO serta mengharapkan akan mendapatkan kepuasan dari produk Telkomsel tersebut.

Pada Gambar 1.1 diatas, terlihat jumlah pengguna baru terus meningkat setiap bulannya, namun kartuHALO tidak sepenuhnya memberikan kepuasan yang diharapkan oleh pengguna. Terdapat beberapa pelanggan yang mengeluh akan kualitas dari kartuHALO. Beberapa keluhan yang terjadi selama tahun 2015 diantaranya adalah :

Tabel 1 Daftar Keluhan Pengguna kartuHALO Selama Tahun 2015

\begin{tabular}{|c|l|c|}
\hline No. & \multicolumn{1}{|c|}{ Keluhan } & Frekuensi \\
\hline 1. & Tagihan (invoice) tidak datang tepat waktu. & $46 \mathrm{kali}$ \\
\hline 2. & Migrasi kartu prabayar ke pascabayar yang relatif lama. & $20 \mathrm{kali}$ \\
\hline 3. & Jaringan yang sering gangguan. & $13 \mathrm{kali}$ \\
\hline 4. & Tagihan dan penggunaan yang tidak sesuai. & $33 \mathrm{kali}$ \\
\hline 5. & $\begin{array}{l}\text { Tiba-tiba tidak bisa digunakan untuk telepon, mengirim } \\
\text { pesan dan internet. }\end{array}$ & $27 \mathrm{kali}$ \\
\hline
\end{tabular}

Sumber: Data Internal GraPARI Telkomsel MTC Bandung (2016)

Tabel diatas adalah daftar keluhan yang diadukan pengguna kartuHALO pada GraPARI Telkomsel MTC Bandung selama Tahun 2015. Dapat dilihat, beberapa pengguna mengeluhkan tentang kualitas kartuHALO yang dirasakan. Setiap terjadi pengaduan atau keluhan dari pengguna, Telkomsel selalu sigap dalam menanganinya, namun hal ini tetap akan berpengaruh pada tingkat kepuasan yang dirasakan oleh pengguna. 
Kualitas produk merupakan hal yang sangat penting karena akan berpengaruh kepada tingkat kepuasan yang dirasakan oleh konsumen atau pengguna dan juga profitabilitas perusahaan itu sendiri. Sedangkan kepuasan pelanggan merupakan kunci bagi perusahaan untuk mempertahankan pelanggan yang ada, karena pelanggan yang puas akan tetap setia untuk waktu yang lebih lama, membeli kembali ketika perusahaan merilis produk baru, memperbaharui produk lama, membicarakan hal-hal baik tentang perusahaan dan produknya kepada orang lain, tidak terlalu memperhatikan produk pesaing dan tidak terlalu sensitif terhadap harga. Sehingga pada akhirnya profitabilitas perusahaan akan meningkat.

Berdasarkan uraian latar belakang diatas, maka judul yang akan diangkat dalam penelitian ini adalah "PENGARUH KUALITAS PRODUK kartuHALO TERHADAP KEPUASAN PENGGUNA (Studi pada GraPARI Telkomsel MTC Bandung)”.

\section{Identifikasi Masalah}

Berdasarkan uraian latar belakang diatas, maka identifikasi masalah dalam penelitian ini adalah sebagai berikut :

1. Bagaimana tingkat kualitas produk kartuHALO?

2. Bagaimana tingkat kepuasan pengguna kartuHALO?

3. Bagaimana pengaruh kualitas produk terhadap kepuasan pengguna kartuHALO?

\section{Tujuan Penelitian}

Tujuan dari penelitian ini adalah sebagai berikut :

1. Untuk mengetahui tingkat kualitas produk kartuHALO.

2. Untuk mengetahui tingkat kepuasan pengguna kartuHALO.

3. Untuk mengetahui pengaruh kualitas produk terhadap kepuasan pengguna kartuHALO.

\section{Hipotesis}

Berdasarkan penjelasan tinjauan pustaka serta kerangka pemikiran, dapat dirumuskan hipotesis penelitian sebagai berikut :

Ho : Tidak terdapat pengaruh kualitas produk terhadap kepuasan pengguna kartuHALO.

$\mathrm{Ha}$ : Terdapat pengaruh kualitas produk terhadap kepuasan pengguna kartuHALO.

\section{Kualitas Produk}

Kualitas produk sangat penting dari sisi produsen maupun konsumen. Purnama (2006:11) mendefinisikan kualitas yang bersumber dari dua sisi yaitu produsen dan konsumen. Produsen menentukan persyaratan atau spesifikasi kualitas, sedangkan konsumen menentukan kebutuhan dan keinginan. Pendefinisian tersebut akan akurat jika produsen mampu menterjemahkan kebutuhan dan keinginan konsumen terhadap suatu produk kedalam spesifikasi produk yang dihasilkan. Sementara itu, Umar (2005:32) mendefinisikan mutu atau kualitas produk sebagai sesuatu yang menunjukkan kemampuan produk untuk menjalankan fungsinya. Sedangkan Thomas (2012:308) juga memiliki pandangan tersendiri yaitu : "Product quality is defined as the collection of features and characteristics of a product that contribute to its ability to meet given requirements" yang artinya "kualitas produk didefinisikan sebagai kumpulan fitur dan karakteristik produk yang berkontribusi terhadap kemampuannya untuk memenuhi persyaratan yang diberikan".

Dari ketiga pendapat diatas dapat simpulkan bahwa kualitas produk adalah kumpulan fitur dan karakteristik produk yang berkontribusi terhadap kemampuannya untuk memenuhi persyaratan yang diberikan, menjalankan fungsinya, dan juga sebagai keinginan atau 
kebutuhan dari konsumen yang diterjemahkan oleh produsen dalam bentuk persyaratan atau spesifikasi tertentu.

Dimensi untuk mengukur kualitas produk yang digunakan dalam penelitian ini adalah dimensi menurut David Garvin (1987) dalam Hidayat (2007:4), diantaranya :

1. Performansi (performance), yaitu berkaitan dengan aspek fungsional dari suatu produk dan merupakan karakteristik utama yang dipertimbangkan atau diharapkan konsumen ketika ingin membeli suatu produk.

2. Fitur (features), merupakan aspek kedua dari performansi yang menambah fungsi dasar, berkaitan dengan pilihan-pilihan dan pengembangannya. Sering kali terdapat kesulitan untuk memisahkan karakteristik performansi dan fitur. Biasanya konsumen mendefinisikan nilai dalam bentuk fleksibilitas dan kemampuan mereka untuk memilih fitur yang ada juga kualitas dari fitur tersebut.

3. Keandalan (reliability), yaitu berkaitan dengan probabilitas atau kemungkinan suatu produk dalam melaksanakan fungsinya secara berhasil dalam periode waktu tertentu di bawah kondisi tertentu. Dengan demikian keandalan merupakan karakteristik yang merefleksikan kemungkinan atau probabilitas tingkat keberhasilan dalam penggunaan produk itu.

4. Konformans atau penyesuaian (conformance), berkaitan dengan tingkat kesesuaian produk terhadap spesifikasi yang telah ditetapkan sebelumnya berdasarkan keinginan konsumen. Konformans merefleksikan derajat dimana karakteristik desain produk dan karakteristik kualitas standar yang telah ditetapkan.

5. Keawetan (durability) yaitu suatu refleksi umur ekonomis berupa ukuran daya tahan atau masa pakai barang.

6. Kemampuan layanan (serviceability), karakteristik yang berkaitan dengan kecepatan, kompetensi, kemudahan dan akurasi dalam memberikan layanan untuk perbaikan barang karena produk yang digunakan untuk jangka waktu yang lama seringkali harus diperbaiki atau dirawat.

7. Estetika (aesthetics), merupakan keadaan produk yang dapat terlihat dan terasa. Estetika adalah karakteristik yang bersifat subyektif mengenai nilai-nilai estetika yang berkaitan dengan pertimbangan pribadi dan refleksi dari preferensi individual.

8. Perceived quality, sifat subyektif yang berkaitan dengan perasaan pelanggan mengenai keberadaan produk tersebut sebagai produk yang berkualitas.

\section{Kepuasan Pengguna}

Siapapun yang terlibat dalam bisnis pastinya memiliki tanggung jawab untuk memuaskan pelanggannya. Kepuasan pelanggan menjadi sesuatu yang sangat penting baik dari perspektif perusahaan maupun konsumen. Kotler dan Amstrong (2008:16) menyebutkan bahwa kepuasan pelanggan tergantung pada kinerja terhadap ekspektasi atau harapan pembeli. Jika kinerja produk tidak memenuhi ekspektasi, pelanggan akan kecewa. Jika kinerja produk sesuai dengan ekspektasi, pelanggan akan puas. Sedangkan jika kinerja produk melebihi ekspektasi, pelanggan akan sangat puas. Khokhar (2011) dalam Umair, Anser dan Qasim (2014:433) mengatakan bahwa "satisfaction come after use of some products or services which is essentially the result of actual and expected functions of product", yang memiliki arti kepuasan datang setelah penggunaan beberapa produk atau jasa yang pada dasarnya adalah hasil dari fungsi yang sebenarnya dan fungsi yang diharapkan dari 
produk tersebut. Sedangkan kepuasan pelanggan menurut Irawan (2004:3) adalah "hasil akumulasi dari konsumen atau pelanggan dalam menggunakan produk dan jasa. Oleh karena itu, setiap transaksi atau pengalaman baru akan memberikan pengaruh terhadap kepuasan pelanggan".

Dari ketiga definisi diatas dapat disimpulkan bahwa kepuasan pengguna adalah hasil akumulasi dari konsumen setelah menggunakan produk atau jasa, yang pada dasarnya adalah hasil dari ekspektasi konsumen dan kinerja produk yang sebenarnya. Jika kinerja produk tidak memenuhi ekspektasi, pelanggan akan kecewa. Jika kinerja produk sesuai dengan ekspektasi, pelanggan akan puas. Sedangkan jika kinerja produk melebihi ekspektasi, pelanggan akan sangat puas.

Dimensi untuk mengukur kepuasan pengguna yang digunakan dalam penelitian ini adalah dimensi menurut Irawan (2004:37), diantaranya :

1. Kualitas produk

Kualitas produk adalah dimensi yang global dan paling tidak terdapat enam elemen dari kualitas produk, yaitu performance, durability, feature, reliability, consistency, dan design.

2. Harga

Bagi pelanggan yang sensitif biasanya harga murah adalah sumber kepuasan yang penting karena mereka akan mendapatkan value for money yang tinggi. Sebaliknya, komponen harga relatif tidak penting bagi mereka yang tidak sensitif terhadap harga.

3. Service quality

Kepuasan terhadap kualitas pelayanan biasanya sulit untuk ditiru. Kualitas pelayanan merupakan penggerak (driver) yang mempunyai banyak dimensi, salah satunya yang populer adalah SERVQUAL. Berdasarkan konsep servqual menyebutkan terdapat lima dimensi, yaitu tangible, reliability, responsiveness, assurance dan emphaty.

4. Emotional factor

Emotional factor (E-factor) adalah faktor pendorong kepuasan pelanggan yang relatif unik. Untuk kategori produk yang berhubungan dengan gaya hidup, faktor ini cukup penting menentukan kepuasan pelanggan. Sedangkan untuk produk-produk yang sifatnya sangat fungsional, faktor kepentingan dari faktor pendorong ini juga relatif kecil.

5. Biaya dan kemudahan

Faktor pendorong yang terakhir dari kepuasan pelanggan adalah kemudahan untuk mendapatkan produk atau jasa. Hal ini termasuk juga berkaitan dengan biaya yang dikeluarkan untuk mendapatkan produk atau jasa tersebut. Pelanggan akan semakin puas apabila relatif mudah, nyaman dan efisien dalam mendapatkan produk atau pelayanan.

Dimensi yang akan digunakan untuk mengukur kepuasan pengguna adalah dimensi yang dianggap sesuai dengan kondisi yang ada. Dimensi yang digunakan adalah harga, emotional factors, serta biaya dan kemudahan. 


\section{Kerangka Pemikiran}

Berikut ini adalah kerangka pemikiran dalam penelitian ini :

\section{Gambar 2 Kerangka Pemikiran Pengaruh Kualitas Produk terhadap Kepuasan Pengguna}

\begin{tabular}{|c|c|}
\hline 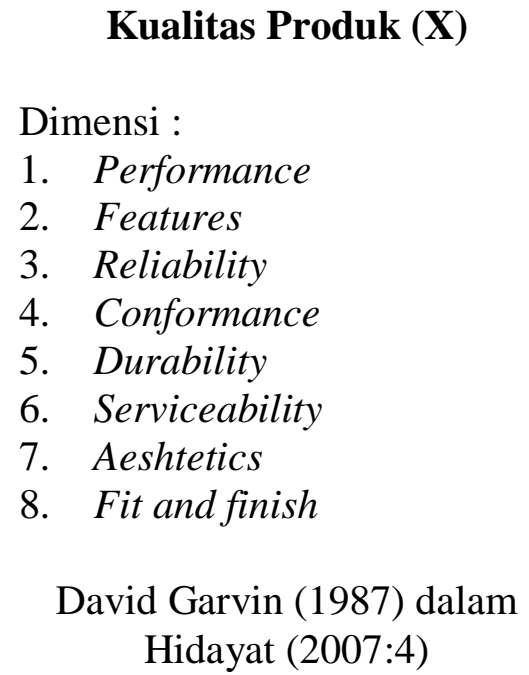 & $\begin{array}{l}\text { Kepuasan Pengguna (Y) } \\
\text { Dimensi : } \\
\text { 1. Harga } \\
\text { 2. Emotional factor } \\
\text { 3. Biaya dan kemudahan }\end{array}$ \\
\hline
\end{tabular}

Sumber: Data Olahan Penulis (2016)

\section{Metode Penelitian}

Metode yang digunakan dalam penelitian ini adalah metode penelitian kuantitatif. Populasi dalam penelitian ini adalah seluruh pengguna baru kartuHALO pada GraPARI Telkomsel MTC Bandung selama Tahun 2015, yaitu sebanyak 1.176 orang. Sedangkan metode pengambilan sampel yang digunakan adalah metode non probability sampling dimana didalamnya terdapat teknik incidental sampling, yaitu teknik penentuan sampel berdasarkan kebetulan, yaitu siapa saja yang secara kebetulan/insidental bertemu dengan peneliti dapat digunakan sebagai sampel, bila dipandang orang yang kebetulan ditemui itu cocok dengan sumber data (Sugiyono, 2014:120). Sampel yang digunakan sebanyak 270 responden. Data penelitian terdiri dari primer yaitu yang berasal dari kuesioner dan hasil wawancara, dan sekunder yang berasal dari studi pustaka dan data perusahaan.

Dalam penelitian ini, kuesioner yang digunkaan didesain dengan menggunakan skala likert dengan bobot nilai 1 sampai dengan 5. Uji validitas dan reliabilitas telah dilakukan dengan memberi hasil bahwa semua pernyataan adalah valid dilihat dari nilai corrected itemtotal correlations yang memiliki nilai lebih dari 0,30 (Sugiyono, 2013:178). Selain itu kedua variabel adalah reliabel, karena keduanya memiliki nilai cronbach's alpha yang lebih dari 0,60 (Sekaran, 2006:182) yaitu nilai variabel kualitas produk sebesar 0,902 dan nilai variabel kepuasan pengguna sebesar 0,827. Analisis dilakukan dengan menggunakan uji asumsi klasik, analisis deskriptif, analisis regresi, analisis korelasi, koefisien determinasi dan uji hipotesis. 


\section{Hasil Identitas Responden}

Berikut ini adalah profil responden dalam penelitian ini :

Tabel 2 Identitas Responden

\begin{tabular}{|c|c|c|c|}
\hline \multirow[t]{2}{*}{ Jenis kelamin } & Pria & 141 orang & $52,2 \%$ \\
\hline & Wanita & 129 orang & $47,8 \%$ \\
\hline \multirow[t]{6}{*}{ Usia } & 16-20 Tahun & 16 orang & $5,9 \%$ \\
\hline & 21-25 Tahun & 54 orang & $20 \%$ \\
\hline & 26-30 Tahun & 42 orang & $15,6 \%$ \\
\hline & 31-35 Tahun & 46 orang & $17 \%$ \\
\hline & 36-40 ahun & 62 orang & $23 \%$ \\
\hline & $>41$ Tahun & 50 orang & $18,5 \%$ \\
\hline \multirow[t]{6}{*}{ Pekerjaan } & Pelajar/Mahasiswa & 48 orang & $17,8 \%$ \\
\hline & TNI/POLRI & 17 orang & $6,3 \%$ \\
\hline & Pegawai Negeri & 28 orang & $10,4 \%$ \\
\hline & Pegawai Swasta & 85 orang & $31,5 \%$ \\
\hline & Wiraswasta & 65 orang & $24,1 \%$ \\
\hline & Lain-lain & 27 orang & $10 \%$ \\
\hline
\end{tabular}

Sumber: Data Olahan SPSS (2016)

\section{Hasil Analisis Deskriptif Kualitas Produk}

Tabel 3 Deskriptif Varibale Kualitas Produk

\begin{tabular}{|l|r|r|r|r|r|}
\hline & $\mathrm{N}$ & Minimum & Maximum & Mean & Std. Deviation \\
\hline & & & & \\
Performance & 270 & 2 & 5 & 4,14 &, 521 \\
Features & 270 & 2 & 5 & 4,03 &, 549 \\
Reliability & 270 & 2 & 5 & 3,87 &, 600 \\
Conformance & 270 & 2 & 5 & 3,98 &, 476 \\
Durability & 270 & 2 & 5 & 3,86 &, 652 \\
Serviceability & 270 & 2 & 5 & 4,03 &, 506 \\
Aesthetics & 270 & 2 & 5 & 3,97 &, 531 \\
Perceived quality & 270 & 3 & 5 & 4,09 &, 494 \\
Kualitas Produk (X) & $\mathbf{2 7 0}$ & $\mathbf{3}$ & $\mathbf{5}$ & $\mathbf{3 , 9 8}$ &, 385 \\
Valid N (listwise) & 270 & & & \\
\hline
\end{tabular}

Sumber: Data Olahan SPSS (2016)

Analisis deskriptif variabel kualitas produk digunakan untuk menjawab identifikasi masalah yang pertama yaitu bagaimana kualitas produk kartuHALO. Berdasarkan Tabel 3, dapat dilihat bahwa kualitas produk kartuHALO berada dalam kategori baik, terbukti dengan nilai mean 3,98. Serta nilai standar deviasi sebesar 0,385 atau 9,67\% dari nilai mean-nya 
yang berarti standar deviasi tidak lebih dari $20 \%$ dan menunjukkan bahwa variasi jawaban kecil atau sebagaian besar responden menjawab pernyataan dalam variabel ini dengan jawaban yang relatif sama. Kedelapan dimensi yang terdapat dalam variabel kualitas produk juga berada dalam kategori baik.

Dimensi pertama dalam variabel kualitas produk adalah performance, yang merupakan dimensi dengan nilai mean tertinggi yaitu sebesar 4,14. Dalam dimensi ini terdapat 3 indikator yaitu sesuai kebutuhan, memberi kemudahan dan memenuhi harapan, dimana ketiga indikator tersebut memiliki nilai mean yang berada dalam kategori baik. Menurut Sijintak (2004:7) performance atau kinerja merupakan dimensi yang paling dasar karena konsumen akan merasa kecewa apabila harapan mereka terhadap dimensi ini tidak terpenuhi. Kemudian David Garvin (1987) dalam Hidayat (2007:4) mendefinisikan performance sebagai sesuatu yang berkaitan dengan aspek fungsional dari suatu produk dan juga merupakan karakteristik utama yang dipertimbangkan atau diharapkan konsumen ketika ingin membeli suatu produk. Berdasarkan hasil analisis menggunakan program SPSS, dimensi performance atau kinerja memiliki nilai mean tertinggi pada variabel kualitas produk. Hal ini menunjukkan bahwa kartuHALO telah memiliki kualitas yang baik sehingga aspek fungsional dan karakteristik utama yang menjadi harapan pengguna dapat terpenuhi. Selain itu, pengguna juga menganggap bahwa kartuHALO telah sesuai dengan kebutuhan dan harapan, serta memberikan berbagai kemudahan bagi pengguna.

Dimensi kedua yaitu feature, dengan nilai mean sebesar 4,03. Dimensi feature memiliki 3 indikator yaitu fitur sesuai kebutuhan, fitur memuaskan dan fitur inovatif, dimana ketiganya memiliki nilai mean yang berada dalam kategori baik. Sijintak (2004:7) mengartikan feature sebagai aspek sekunder dengan perkembangannya yang hampir tidak terbatas sejalan dengan perkembangan teknologi, serta menjadi target inovasi bagi produsen untuk memuaskan pelanggan. Menurut hasil analisis yang dilakukan, kartuHALO dapat dikatakan memiliki fitur yang baik. Hasil analisis juga didukung dengan jawaban responden yang mengganggap bahwa fitur yang ditawarkan oleh kartuHALO sesuai dengan kebutuhan, inovatif sejalan dengan perkembangan teknologi serta fitur-fitur yang memberikan kepuasan. Hal tersebut membuktikan bahwa Telkomsel sebagai penyedia layanan berusaha memuaskan pengguna dengan menawarkan fitur-fitur terbaik dalam provider kartuHALO dan mengembangkan fitur-fitur yang dimilikinya sesuai dengan perkembangan teknologi.

Dimensi ketiga adalah reliability, dengan nilai mean sebesar 3,87. Dimensi ini memiliki 3 indikator yaitu tidak mengalami gangguan, berfungsi dengan baik dan simcard tidak pernah rusak, dimana ketiganya memiliki nilai mean yang berada dalam kategori baik. Namun apabila dilihat dari nilai standar deviasi indikator tidak pernah pengalami gangguan sebesar 0,905 atau $24,45 \%$ dari nilai mean menunjukkan bahwa terdapat variasi jawaban yang besar atau responden menjawab pernyataan ini dengan jawaban yang berbeda-beda, karena gangguan bisa disebabkan oleh banyak faktor. Prawirosentono (2004:8) menyebutkan bahwa produk yang reliabel adalah produk yang memiliki kinerja yang konsisten baik dalam batas-batas perawatan normal. Sedangkan Sijintak (2004:7) mengungkapkan bahwa produk yang reliabel adalah produk yang tidak pernah mengalami kerusakan selama digunakan.

Dimensi keempat yaitu conformance, dengan nilai mean sebesar 3,98. Dimensi ini memiliki 3 indikator yaitu sesuai keinginan pengguna, spesifikasi sesuai janji dan spesifikasi sesuai standar, dimana ketiganya memiliki nilai mean yang berada dalam kategori baik. Purnama (2006:11) mendefinisikan kualitas bersumber dari dua sisi yaitu produsen dan konsumen. Produsen menentukan persyaratan atau spesifikasi kualitas, sedangkan konsumen 
menentukan kebutuhan dan keinginan. Pendefinisian tersebut akan akurat jika produsen mampu menterjemahkan kebutuhan dan keinginan konsumen terhadap suatu produk kedalam spesifikasi produk yang dihasilkan. Berdasarkan hasil analisis menggunakan bantuan program SPSS dan definsi dari Purnama, membuktikan bahwa Telkomsel sebagai penyedia layanan berusaha untuk memahami keinginan dan kebutuhan pengguna, serta mampu menterjemahkannya, setelah itu menyusunnya menjadi sebuah standar atau spesifikasi yang terdapat pada kartuHALO.

Dimensi kelima adalah durability, dengan nilai mean sebesar 3,86. Dimensi durability memiliki 3 indikator yaitu keawetan simcard, simcard tidak mudah rusak dan kinerja konsisten yang mana ketiganya berada dalam kategori baik. Menurut Sijintak (2004:7) durability atau keawetan adalah suatu pengukuran terhadap siklus produk, baik secara teknis maupun waktu. Produk dapat dikatakan awet apabila sudah digunakan berulang kali atau sudah lama. Tidak ada yang bisa menjamin mengenai keawetan suatu barang karena itu tergantung bagaimana penggunaannya. Hal tersebut dalam dilihat dari nilai standar deviasi dari 2 indikator dalam dimensi ini yang melebihi $20 \%$ nilai mean-nya.

Dimensi keenam yaitu serviceability, dengan nilai mean sebesar 4,03. Dimensi ini memiliki 3 indikator yaitu kemudahan service, kecepatan GraPARI dan kecepatan Telkomsel, dimana ketiganya memiliki nilai mean yang berada dalam kategori baik. Prawirosentono (2004:8) menyebutkan bahwa produk yang bermutu baik harus pula memenuhi kemudahan untuk diperbaiki atau dirawat, sehingga produk tersebut dapat beroperasi secara baik. Sedangkan David Garvin (1987) dalam Hidayat (2007:4) menambahkan bahwa dimensi ini berkaitan dengan kecepatan, kompetensi, kemudahan dan akurasi dalam memberikan layanan untuk perbaikan produk. Menurut hasil analisis yang diolah dengan program SPSS, responden menganggap bahwa responden dapat dengan mudah melakukan service apabila terjadi gangguan pada kartuHALO. Apabila kartuHALO mengalami gangguan, responden dapat datang ke GraPARI Telkomsel untuk mendapatkan service tanpa dipungut biaya. Setelah menerima keluhan dari pengguna, pihak GraPARI akan segera melakukan perbaikan pada kartuHALO. Hal ini berkaitan dengan indikator kedua yang merupakan indikator dengan nilai mean tertinggi pada dimensi ini yaitu kecepatan GraPARI dalam memberikan pelayanan. Indikator terakhir pada dimensi ini adalah kecepatan Telkomsel dalam memperbaiki apabila terjadi gangguan yang merupakan indikator dengan nilai mean terendah yaitu sebesar 3,96. Pada kenyataannya, jika terjadi gangguan pada jaringan, Telkomsel tidak dapat secara langsung memperbaiki pada saat itu juga, dikarenakan gangguan ini berhubungan langsung dengan satelit, sehingga membutuhkan waktu yang relatif lebih lama untuk memperbaiki dan normal kembali.

Dimensi ketujuh yaitu aesthetics, dengan nilai mean sebesar 3,97. Dimensi aesthetics memiliki 3 indikator yaitu desain menarik, ciri khas kartuHALO dan desain simcard, yang dimana ketiganya memiliki nilai mean yang berada dalam kategori baik. Menurut David Garvin (1987) dalam Hidayat (2007:4) estetika (aesthetics) merupakan keadaan produk yang dapat terlihat dan terasa. Estetika adalah karakteristik yang bersifat subyektif mengenai nilainilai estetika yang berkaitan dengan pertimbangan pribadi dan refleksi dari preferensi individual. Dari nilai mean yang didapatkan dimensi ini membuktikan bahwa kartuHALO memiliki estetika yang baik.

Dimensi kedelapan yaitu perceived quality, dengan nilai mean sebesar 4,09. Dimensi ini memiliki 3 indikator yaitu senang menggunakan kartuHALO, kualitas kartuHALO dan kartuHALO unggul, dimana ketiganya memiliki nilai mean yang berada dalam kategori baik. 
David Garvin (1987) dalam Hidayat (2007:4) menyebutkan bahwa perceived quality merupakan sifat subyektif yang berkaitan dengan perasaan pelanggan mengenai keberadaan produk tersebut sebagai produk yang berkualitas. Dilihat dari ketiga indikator dalam dimensi ini, menunjukkan bahwa kartuHALO memiliki perceived quality yang baik. 


\section{Hasil Analisis Deskriptif Kepuasan Pengguna}

Tabel 4 Deskriptif Variabel Kepuasan Pengguna

\begin{tabular}{|l|r|r|r|r|r|}
\hline & $\mathrm{N}$ & Minimum & Maximum & Mean & Std. Deviation \\
\hline Harga & 270 & 2 & 5 & 3,66 &, 749 \\
Emotional Factors & 270 & 3 & 5 & 4,02 &, 455 \\
Biaya dan kemudahan & 270 & 1 & 5 & 3,85 &, 694 \\
Kepuasan Pengguna (Y) & $\mathbf{2 7 0}$ & $\mathbf{2}$ & $\mathbf{5}$ & $\mathbf{3 , 8 5}$ &, $\mathbf{5 0 1}$ \\
Valid N (listwise) & 270 & & & \\
\hline
\end{tabular}

Sumber: Data Olahan SPSS (2016)

Analisis deskriptif variabel kepuasan pengguna digunakan untuk menjawab identifikasi masalah yang kedua yaitu bagaimana kepuasan pengguna kartuHALO. Berdasarkan Tabel 4, dapat dilihat bahwa kepuasan pengguna kartuHALO berada dalam kategori baik, terbukti dengan nilai mean 3,85. Serta nilai standar deviasi sebesar 0,501 atau $13,01 \%$ dari nilai mean-nya yang berarti standar deviasi tidak lebih dari $20 \%$ dan menunjukkan bahwa variasi jawaban kecil atau sebagaian besar responden menjawab pernyataan dalam variabel ini dengan jawaban yang relatif sama. Ketiga dimensi yang terdapat dalam variabel kepuasan pengguna juga berada dalam kategori baik.

Dimensi pertama yaitu harga. Harga merupakan dimensi dalam variabel kepuasan pengguna dengan nilai mean terendah yaitu sebesar 3,66. Dimensi harga memiliki 3 indikator yaitu harga sesuai kualitas, harga terjangkau dan tidak terbebani biaya, yang ketiganya memiliki nilai mean yang berada dalam kategori baik. Namun dilihat dari standar deviasi dimensi harga sebesar 0,749 atau 20,46\% dari nilai mean, menunjukkan bahwa terdapat variasi jawaban yang besar atau sebagian responden menjawab pernyataan dengan jawaban yang relatif berbeda.

Dimensi kedua yaitu emotional factors yang merupakan dimensi yang memiliki nilai mean tertinggi dalam variabel kepuasan pengguna yaitu sebesar 4,06. Dimensi ini memiliki 3 indikator yaitu bangga mengguna kartuHALO, citra baik Telkomsel dan puas dengan kinerja yang ketiganya memiliki nilai mean yang berada dalam kategori baik. Dan dilihat dari nilai standar deviasinya, setiap indikator menunjukkan variasi jawaban yang relatif kecil atau responden yang menjawab dengan jawaban yang relatif sama. Menurut David Garvin (1987) dalam Hidayat (2007:4) emotional factor (E-factor) adalah faktor pendorong kepuasan pelanggan. Untuk kategori produk yang berhubungan dengan gaya hidup, faktor ini cukup penting menentukan kepuasan pelanggan. Didalam emotional factor terdapat tiga aspek yaitu estetika, self-expressive value, dan brand personality. Hal tersebut membuktikan bahwa kartuHALO telah memenuhi dimensi emotional factors.

Dimensi ketiga yaitu biaya dan kemudahan dengan nilai mean sebesar 3,85. Dimensi ini memiliki 3 indikator yaitu mudah mendapatkan kartuHALO, mudah mendaftar dan biaya terjangkau, dimana ketiganya memiliki nilai mean yang berada dalam kategori baik. Apabila dilihat dari nilai standar deviasinya, ketiga indikator menunjukkan nilai standar deviasi yang melebihi $20 \%$ dari nilai mean-nya, artinya responden menjawab dengan jawaban yang relatif berbeda-beda. Pada kenyataannya, untuk menggunakan provider kartuHALO, calon pengguna terlebih dahulu harus mendatangi GraPARI Telkomsel atau Gerai Telkomsel. Lalu calon pengguna dapat mendaftar dengan memberikan data diri, untuk mendaftar menggunakan provider kartuHALO tidak dikenakan biaya apapun (biaya simcard ataupun biaya administrasi). Setelah itu kartuHALO dapat digunakan. Pada dimensi ini, indikator 
mudah mendapatkan kartuHALO memiliki nilai mean terendah disebabkan oleh sebagian orang merasa sulit mendapatkan kartuHALO karena harus terlebih dahulu mendatangi GraPARI atau Gerai Telkomsel.

\section{Hasil Analisis Regresi}

Tabel 5 Analisis Regresi Sederhana

\begin{tabular}{|rl|r|r|r|r|r|}
\hline \multirow{2}{*}{ Model } & \multicolumn{2}{|c|}{ Unstandardized Coefficients } & \multicolumn{1}{|c|}{$\begin{array}{c}\text { Standardized } \\
\text { Coefficients }\end{array}$} & \multirow{2}{*}{ Sig. } \\
\cline { 3 - 5 } & \multicolumn{2}{|r|}{ B } & Std. Error & Beta & & \\
\hline \multirow{2}{*}{1} & (Constant) & 7,483 & 2,325 & & 3,218 &, 001 \\
& Kualitas produk &, 283 &, 024 &, 582 & 11,719 &, 000 \\
\hline
\end{tabular}

a. Dependent Variable: Kepuasan pengguna

Sumber: Data Olahan SPSS (2016)

Berdasarkan Tabel 5 diperoleh konstanta (a) bernilai 7,483 dengan koefisien regresi (b) 0,283 menggambarkan persamaan regresi yang dapat dilihat pada kolom Unstandardized Coefficients sebagai berikut :

$$
\begin{aligned}
& Y=a+b X \\
& Y=7,483+0,283 X
\end{aligned}
$$

Dimana :

$\mathrm{Y}=$ Kepuasan pengguna

$\mathrm{X}=$ Kualitas produk

Dari persamaan tersebut dapat dijelaskan untuk nilai konstanta sebesar 7,483 yang berarti apabila tidak ada nilai X (kualitas produk kartuHALO), maka nilai Y (kepuasan pengguna kartuHALO) adalah 7,483. Untuk nilai koefisien regresi variabel $X$ (kualitas produk kartuHALO) sebesar 0,283 menyatakan bahwa setiap penambahan sebesar satu (1) akan meningkatkan variabel Y (kepuasan pengguna) sebesar 0,283. Namun sebaliknya, jika nilai variabel $\mathrm{X}$ turun sebesar satu (1), maka variabel $\mathrm{Y}$ akan mengalami penurunan sebesar 0,283 .

Selain itu tanda tambah (+) menyatakan arah hubungan yang searah, dimana kenaikan atau penurunan nilai kualitas produk kartuHALO akan mengakibatkan kenaikan atau penurunan kepuasan pengguna.

\section{Hasil Analisis Korelasi}

Tabel 6 Analisis Korelasi

\begin{tabular}{|ll|r|r|}
\hline & Kualitas produk & $\begin{array}{r}\text { Kepuasan } \\
\text { pengguna }\end{array}$ \\
\hline Kualitas produk & Sig. (2-tailed) & 1 &, $582^{* *}$ \\
& $\mathrm{~N}$ & 270 &, 000 \\
& Pearson Correlation &, $582^{* *}$ & 270 \\
Kepuasan pengguna & Sig. (2-tailed) &, 000 & 1 \\
& $\mathrm{~N}$ & 270 & 270 \\
\hline
\end{tabular}

**. Correlation is significant at the 0.01 level (2-tailed).

Sumber: Data Olahan SPSS (2016) 
Berdasarkan Tabel 6 dapat dilihat dari nilai korelasi antara variabel kualitas produk dan kepuasan pengguna sebesar 0,582 yang termasuk kedalam interval +0,50 s/d +0,69 yang artinya terdapat hubungan positif yang kuat (substantial). Nilai korelasi Pearson menunjukkan nilai positif, maka hubungan antara kualitas produk dan kepuasan pengguna searah, yang artinya jika kualitas produk meningkat maka akan diikuti dengan peningkatan kepuasan pengguna. Serta nilai signifikansi sebesar 0,000, dalam kriteria pengujian menurut Sugiama (2008:229), jika sig < 0,05 maka korelasi tersebut signifikan. Sebaliknya korelasi tidak signifikan jika sig $>0,05$. Karena nilai signifikansi sebesar 0,000 $<0,05$ maka dapat disimpulkan bahwa terdapat hubungan yang signifikan antara kualitas produk dan kepuasan pengguna.

\section{Hasil Analisis Koefisien Determinasi}

Tabel 7 Analisis Koefisien Determinasi

\begin{tabular}{|l|r|r|r|r|}
\hline Model & \multicolumn{1}{|c|}{$\mathrm{R}$} & \multicolumn{1}{|c|}{ R Square } & \multicolumn{1}{|l|}{$\begin{array}{l}\text { Adjusted R } \\
\text { Square }\end{array}$} & $\begin{array}{l}\text { Std. Error of the } \\
\text { Estimate }\end{array}$ \\
\hline 1 &, $582^{\mathrm{a}}$ &, 339 &, 336 & 3,639 \\
\hline
\end{tabular}

a. Predictors: (Constant), Kualitas produk

b. Dependent Variable: Kepuasan pengguna

Sumber: Data Olahan SPSS (2016)

Dari tabel diatas, dapat diketahui bahwa nilai koefisien determinasi atau $R$-Square yang diperoleh adalah 0,339 atau 33,9\%. Hal ini menunjukkan bahwa kualitas produk memberikan kontribusi hubungan sebesar 33,9\% sedangkan sisanya $66,1 \%$ dipengaruhi oleh faktor-faktor lain.

\section{Hasil Uji Hipotesis (Uji F)}

\section{Tabel 8 Hasil Uji Statistik F}

\begin{tabular}{|c|c|c|c|c|c|c|}
\hline \multicolumn{2}{|c|}{ Model } & Sum of Squares & df & Mean Square & $\mathrm{F}$ & Sig. \\
\hline \multirow{3}{*}{1} & Regression & 1818,906 & 1 & 1818,906 & 137,335 &, $000^{\mathrm{b}}$ \\
\hline & Residual & 3549,479 & 268 & 13,244 & & \\
\hline & Total & 5368,385 & 269 & & & \\
\hline
\end{tabular}

a. Dependent Variable: Kepuasan pengguna

b. Predictors: (Constant), Kualitas produk

Sumber: Data Olahan SPSS (2016)

Berdasarkan tabel diatas, dapat dilihat bahwa angka significant pada kolom Sig. Adalah 0,000. Nilai tersebut lebih kecil dibandingkan dengan nilai probabilitasnya yang nilainya sebesar $0,05(5 \%)$. Apabila dilihat dari nilai $F$ hitung $\left(\mathrm{F}_{0}\right)$ yang terlihat pada kolom $\mathrm{F}$ yang besarnya 137,335 dengan menggunakan tingkat signifikan 0,05 serta $\mathrm{df}_{1}:(\mathrm{k}-1)=2-1$ $=1$ dan $\mathrm{df}_{2}:(\mathrm{n}-\mathrm{k})=270-2=268$, maka diperoleh $\mathrm{F}$ tabel $\left(\mathrm{F}_{1}\right)$ sebesar 3,8415 yang berarti bahwa nilai $F_{0} \geq F_{t}$ yaitu $137,335 \geq 3,8415$. Mengacu pada hasil uji statistik $F$ menurut Arikunto (2010:368), jika kriteria $\mathrm{F}_{0} \geq \mathrm{F}_{\mathrm{t}}$ dengan taraf signifikansi 5\% maka interpretasinya adalah $\mathrm{H}_{0}$ ditolak dan $\mathrm{H}_{\mathrm{a}}$ diterima. Hal tersebut menunjukkan bahwa kualitas produk kartuHALO berpengaruh positif dan signifikan terhadap kepuasan pengguna. 


\section{Hasil Uji Hipotesis (Uji T)}

Uji T digunakan untuk mengetahui apakah kualitas produk berpengaruh signifikan terhadap kepuasan pengguna. Hasil uji $\mathrm{T}$ dapat dilihat pada Tabel 5 mengenai hasil uji regresi linier sederhana. Angka significant pada kolom Sig. adalah 0,000. Nilai tersebut lebih kecil dibandingkan dengan nilai probabilitasnya yang nilainya sebesar $0,05(5 \%)$.

Apabila dilihat dari nilai t hitung yang terlihat pada kolom t yang besarnya 11,719 dengan menggunakan tingkat signifikansi 0,05 dan df $:(n-k)=270-2=268$, maka diperoleh $\mathrm{t}$ tabel sebesar 1,650559 yang berarti bahwa nilai $\mathrm{t}$ hitung $>\mathrm{t}$ tabel yaitu 11,719 $\geq 1,650559$. Mengacu pada pendapat Priyatno (2013:114) yang menyatakan bahwa jika kriteria t hitung > $\mathrm{t}$ tabel dan tingkat signifikansi $<0,05$ maka interpretasinya adalah $\mathrm{H}_{0}$ ditolak dan $\mathrm{H}_{\mathrm{a}}$ diterima. Hal tersebut menunjukkan bahwa kualitas produk kartuHALO berpengaruh positif dan signifikan terhadap kepuasan pengguna.

\section{Kesimpulan}

Berdasarkan hasil pengumpulan data, pengolahan data dan analisis yang telah dilakukan, maka dapat ditarik kesimpulan. Kesimpulan ini sekaligus menjawab perumusan masalah dari penelitian, yaitu sebagai berikut :

1. Kualitas produk KartuHALO berada pada kategori baik dan kedelapan dimensi dari variabel ini yaitu performance, features, reliability, conformance, durability, serviceability, aesthetics, dan perceived quality berada pada kategori yang baik pula. Dimensi performance merupakan dimensi dengan nilai mean tertinggi, sedangkan dimensi durability merupakan dimensi dengan nilai mean terendah. Indikator dengan nilai mean terendah ditunjukkan oleh indikator tidak mengalami gangguan yang terdapat pada dimensi reliability, tetapi indikator ini masih berada pada kategori baik.

2. Kepuasan pengguna KartuHALO di GraPARI Telkomsel MTC Bandung berada pada kategori baik dan ketiga dimensi dari variabel ini yaitu harga, emotional factors serta biaya dan kemudahan berada pada kategori baik pula. Emotional factors menjadi dimensi dengan nilai mean tertinggi, sedangkan harga menjadi dimensi dengan nilai mean terendah. Indikator dengan nilai mean terendah adalah indikator harga terjangkau dan tidak terbebani biaya yang berapa pada dimensi harga, tetapi indikator ini masih berada pada kategori baik.

3. Besarnya pengaruh kualitas produk KartuHALO terhadap kepuasan pengguna di GraPARI Telkomsel MTC Bandung yaitu sebesar 33,9\% sementara sisanya 66,1\% dipengaruhi oleh faktor-faktor lain yang tidak dijelaskan dalam penelitian ini.

\section{Saran}

Berikut ini adalah beberapa saran yang berhubungan dengan penelitian yang dilakukan, yang dimaksudkan untuk memberikan masukan yang positif, antara lain sebagai berikut :

1. Sebaiknya simcard kartuHALO perlu diperbaiki menjadi lebih fleksibel agar tidak mudah patah dan rusak, serta sebaiknya diberikan sosialisasi mengenai penggunaan simcard yang baik dan benar kepada pengguna sehingga dapat digunakan dalam jangka waktu panjang. 
2. Sebaiknya harga KartuHALO perlu disesuaikan dengan kualitas yang terdapat didalamnya.

3. Untuk penelitian selanjutnya sebaiknya dilakukan dengan menggunakan variabel lain yang juga dapat mempengaruhi kepuasan pengguna, sehingga $66,1 \%$ faktor lain yang mempengaruhi kepuasan pengguna dalam penelitian ini dapat terjawab.

\section{Daftar Pustaka}

Arikunto, Suharsimi. 2010. Prosedur Penelitian Suatu Pendekatan Praktis. Jakarta: Rineka Cipta

Hidayat, Anang. 2007. Strategi Six Sigma Peta Pengembangan Kualitas dan Kinerja Bisnis. Jakarta: PT Elex Media Komputindo

Irawan, Handi. 2004. 10 Prinsip Kepuasan Pelanggan. Cetakan pertama.Jakarta: PT Elex Media Komputindo

Kotler, P dan Amstrong, Gary. 2008. Prinsip-prinsip Pemasaran. Diterjemahkan oleh: Bob Sabran. Tahun terjemah: 2006. Jakarta: Penerbit Erlangga

Prawirosentono, Suyadi. 2004. Filosofi Baru Tentang Manajemen Mutu Terpadu Total Quality Management Abad 21 Studi Kasus \& Analisis. Jakarta: PT Bumi Aksara

Priyatno, Duwi. 2013. Mandiri Belajar Analisis Data dengan SPSS. Yogyakarta: Mediakom

Purnama, Nursya'bani. 2006. Manajemen Kualitas Perspektif Global. Yogyakarta: Ekonisia

Sekaran, Uma. 2006. Metode Penelitian untuk Bisnis. Jakarta: Jayakarsa

Sitinjak, Tony., et al. 2004. Model Matriks Konsumen untuk Menciptakan Superior Customer Value. Jakarta: PT Gramedia Pustaka Utama

Sugiama, Gima., 2008. Metode Riset Bisnis dan Manajemen. Edisi pertama. Bandung: Penerbit Guardaya Intimarta

Sugiyono. 2013. Metode Penelitian Kualitatif, Kuantitatif dan Kombinasi (Mixed Methods). Bandung: Alfabeta

Sugiyono. 2014. Metode Penelitian Bisnis (Pendekatan Kuantitatif, Kualitatif dan R\&D). Cetakan ke-18. Bandung: Penerbit Alfabeta

Thomas, Sam. 2012. Impact of Product Quality, Service Quality and Contextual Experience on Customer Perceived Value and Future Buying Intentions. Vol.3, No.3. European Journal of Business and Management. Kochi: Cochin University of Science and Technology. 3 Juni 2016

Umar, Husein. 2005. Riset Pemasaran dan Perilaku Konsumen. Jakarta: PT Gramedia Pustaka Utama

Umair, Muhammad Abu., Anser, Fiaz., Qasim, Rashid. 2014. Determinants of Customer Satisfaction and its Impact on Customer Loyalty in Nokia Brand. Vol.5, No.1. Journal of Sociological Research. The Islamia University of Bahawalpur. 29 Mei 2016 